\title{
Synthesis and Characterization of Butadiene-1,3 and 0ctene-1 Copolymer Prepared by a Ziegler-Natta Catalyst Based on Neodymium
}

\author{
Gustavo M. Silva, Fernanda M. B. Coutinho*, Ivana L. Mello, Marcos A. S. Costa \\ Instituto de Química, UERJ \\ Daniele F. C. Junger \\ Teadit Indústria e Comércio Ltda
}

\begin{abstract}
The aim of this work is to evaluate the influence of octene-1 incorporation in the polybutadiene chain on the polymerization reaction and polymer characteristics. Thus, copolymerization of butadiene-1,3 with octene-1 using a Ziegler-Natta ternary catalyst based on neodymium was performed. The weight ratios of butadiene-1,3/ $\alpha$-olefin 100/0, 99/1, 97/3, 95/5, 90/10, 80/20 and 70/30 were evaluated. The copolymers were characterized by size exclusion chromatography (SEC), infrared spectroscopy (FTIR) and thermogravimetric analysis (TG). The results showed that the degradation temperature (Tmax) was not affected by the addition of alpha-olefin, while the thermal behavior has undergone significant changes. The polymer microstructure was not influenced by the increasing of octene-1 content. However, a tendency to molecular mass increase was observed with the increasing of octene- 1 content. It was also observed a trend in reduction of the polymerization conversion as the octene-1 content increased.
\end{abstract}

Keywords: High-cis polybutadiene, copolymerization, octene-1, Ziegler-Natta catalyst.

\section{Introduction}

Polydienes, such as high cis-polybutadiene (cis microstructure up to $99 \%$ ), can be produced by Ziegler-Natta catalyst based on different neodymium's salts. Although these catalyst systems produce a polymer with good mechanical properties, especially higher tensile strength, lower heat buildup, and better abrasion resistance, the polymer chains are highly linear, which make difficult the processability of the material ${ }^{[1-8]}$.

Some procedures can be carried out to improve the processability of polydienes, such as the insertion of some branches into polymer chain ${ }^{[3,9-12]}$, copolymerization of dienes with oligomers ${ }^{[13]}$, copolymerization of dienes and $\alpha$-olefin with different lengths chains ${ }^{[14-16]}$, insertion of branches with chain-end functionalized $^{[17-26]}$.

Visseaux et al. ${ }^{[14]}$ copolymerized isoprene with $\alpha$-olefins of different lengths (from 6 to 18 carbons) and concluded that only a single chain of $\alpha$-olefin was inserted between two units of trans-polyisoprene. In addition, the $\alpha$-olefins length affected the copolymer's properties. The incorporation of olefins with 6-10 carbons induced the loss of crystallinity, resulting in an almost amorphous copolymer. However, the introduction of long chains (18 carbons) did not prevent the crystallization (a partially crystalline material was obtainded).

The introduction of branches in the polymer linear chain leads to various advantages. Rubbers with long branches trend to become rigid when elongated, because the long branches prevent the entanglements from sliding, which act as a resistance to deformation. The short branches, under stress, escape easily from the entanglements and align with the polymer chain, provoking a softening under stretching ${ }^{[2]}$.

Barbier-Baudry et al. ${ }^{[16]}$ utilized a non-hindered ansa dicyclopentadienylallyl complexes of samarium, $\left[\left(\mathrm{CMe}_{2} \mathrm{C}_{5} \mathrm{H}_{4}\right)_{2} \mathrm{Sm}(\text { allyl })\right]_{\mathrm{n}}$, and $\left(\mathrm{CMe}_{2} \mathrm{C}_{5} \mathrm{H}_{4}\right)_{2} \mathrm{Sm}$ (allyl)L ( L = THF or allylLi) to polymerize isoprene without an aluminum cocatalyst. The results showed that the polymerizations were highly stereospecific, affording nearly quantitatively 1-4 trans polyisoprene. In addition, the insertion of short alkyl chains causes a great influence in the copolymer thermal and mechanical properties, because they act as internal plasticizers of the amorphous material. Thus, the introduction of comonomers such as, $\alpha$-olefins modifies the structure of copolymer formed, and consequently modifies the final properties ${ }^{[18]}$.

Makovetsky et al. ${ }^{[13]}$ proposed a route for the preparation of branched polybutadiene, in which butadiene is copolymerized with a macromonomer (polybutadiene of low molecular mass containing a conjugated system of double bonds at one end of the molecule). The copolymerization reactions were carried out with low content of macromonomer (from 5 to $15 \%$ wt.). Catalyst systems based on neodymium chloride and neodymium versatate were used. The formation of conjugated bonds at the end of the chain, according to the authors, is due to termination of chain reactions, which can be caused either by chain transfer to monomer or by removing the hydrogen $\beta$.

Hwang et al. ${ }^{[26]}$ proposed a synthetic route to produce star-branched polybutadienes $(4,8$, and 12 arms $)$ with ${ }_{3} \mathrm{H}_{6} \mathrm{OSi}\left(\mathrm{CH}_{3}\right)_{2} \mathrm{C}\left(\mathrm{CH}_{3}\right)_{3}, \quad-\mathrm{C}_{3} \mathrm{H}_{6} \mathrm{OH}$, and $-\mathrm{C}_{3} \mathrm{H}_{6}-\mathrm{OSO}_{2} \mathrm{CH}_{2} \mathrm{CF}_{3}$ chain ends. It was used a t-butyldimethylsiloxy-functionalized alkyllithium initiator and the anionic polymerization. The authors obtained three types of polymers consisting of molecules with the same architecture and similar molecular mass, but functionalized with three different terminal groups. The degree of branching was generally greater than $80 \%$ of the target value.

The catalyst system neodymium versatate, diisobutylaluminum hydride (DIBAH) and t-butyl chloride has been studied by our research group ${ }^{[27-29]}$. With this system, linear polybutadienes with equal amounts of cis 99\%, high molecular weights and narrow molecular weight distribution were obtained. Now, the introduction of branches in the polymer chain is needed to improve the processability of these materials. 
In order to improve the processability, the copolymerization of dienes with alpha-olefins has raised interest among scientists. However, there are few studies in literature on this subject. Thus, the aim of this work was to study the incorporation of different contents of octene-1 in polybutadiene chain, using a ternary Ziegler-Natta catalyst based on neodymium, in the polymerization conversion and the copolymer characteristics.

\section{Materials and Methods}

\section{Materials}

The chemicals used in this work were diisobutylaluminum hydride (DIBAH) (Akzo Nobel), neodymium versatate (as hexane solution) (Comar), t-butyl chloride (as hexane solution) (Aldrich Chemical Company, Inc.), hexane (Petroflex Indústria e Comércio S.A. actually LANXESS Elastômeros do Brasil S.A., Brazil), 3,5-di-t-butyl-4-hydroxytoluene (BHT) (Shell Brasil S/A, Brazil), trinonylphenyl phosphyte (TNPP) (GE Specialty Chemicals), butadiene (as hexane solution) (Petroflex Indústria e Comércio S.A. actually LANXESS Elastômeros do Brasil S.A., Brazil), tetrahydrofuran, PA (THF) (Vetec Química Fina Ltda, Brazil), nitrogen (White Martins S/A, Brazil) and octene-1 (Aldrich Chemical Company, Inc.).

\section{Catalyst synthesis}

All material involved in the catalyst synthesis was dried in an oven at $100{ }^{\circ} \mathrm{C}$ for at least 12 hours. The synthesis was carried out in oven-dried nitrogen-purged bottles fitted with rubber septum for 1 hour at $10{ }^{\circ} \mathrm{C}$, under magnetic stirring. The addition order of catalytic components was: DIBAH (Al), neodymium versatate $(\mathrm{Nd})$ and t-butyl chloride $(\mathrm{Cl})$. The molar ratio $\mathrm{Cl} / \mathrm{Nd} / \mathrm{Al}$ was kept constant at $3 / 1 / 11$. After the reaction time, the catalyst was aged for 24 hours at $10{ }^{\circ} \mathrm{C}^{[27-28]}$.

\section{Copolymerization reaction}

The copolymerization was conducted for 2 hours in stainless steel reactor (Parr) $1 \mathrm{~L}$ capacity under pressure of $5 \mathrm{kgf} \mathrm{cm}^{-2}$, and stirring rate of $300 \mathrm{rpm}$. The butadiene-1,3 was added to the system reaction in the form of a solution in hexane at $35 \% \mathrm{wt} / \mathrm{wt}$. The octene- 1 was added as received. The components were added to the reactor in the following order: monomers, solvent (hexane) and catalyst. The octene- 1 was added in the following butadiene/ $\alpha$-olefin ratios $=100 / 0,99 / 1,97 / 3,95 / 5,90 / 10,80 / 20$ and 70/30. The catalytic system was deactivated by the addition of hexane solution of 3,5-di-t-butyl-4-hydroxy-toluene (BHT). The copolymer was coagulated in distillated water heated $\left(75^{\circ} \mathrm{C}\right)$ under vigorous stirring $(600 \mathrm{rpm})$ and then dried in an oven with air circulation at $65^{\circ} \mathrm{C}$ until weight constant.

\section{Characterization of copolymers}

Polymer microstructure was characterized by infrared spectroscopy in Perkin-Elmer equipment, model Spectrum One, as films formed on $\mathrm{KBr}$ cells, prepared from $2 \%$ (wt/v) chloroform solutions. The isomer repeating units contents were obtained from the absorbances at 725 (cis-1,4), 910 (1,2-vinyl), and $965 \mathrm{~cm}^{-1}$ (trans-1,4), according to the method of Kimmer ${ }^{[17]}$ wich considers the sum of the proportions of isomeric units corresponds to the total double bond (100\%).

Polymer molecular weight characteristics were evaluated by size exclusion chromatography (SEC), in a Waters 150-C Plus SEC, fitted with a RI detector at $30{ }^{\circ} \mathrm{C}$, using THF as solvent at $1 \mathrm{~mL} / \mathrm{min}$ flow rate. It was used a universal calibration curve, constructed by using polystyrene monodisperse standards. Polymer solutions $(0.1 \% \mathrm{wt} / \mathrm{wt})$ were filtered through filters of $0.45 \mathrm{~lm}$ pore diameter before injecting in the SEC equipment.

Termogravimetric (TG) and derivative thermogravimetric (DTG) curves of polymers were obtained by using a TA Q50 instrument in a temperature range of $50-700{ }^{\circ} \mathrm{C}$ at constant heating rate of $20{ }^{\circ} \mathrm{C} / \mathrm{min}$, under nitrogen atmosphere. During the heating period, the weight loss and temperature difference were recorded as a function of temperature.

\section{Results and Discussion}

All experiments were performed with the same catalytic system, without variation in reaction conditions. The polymerization conditions were also kept constant.

Polymer was not obtained when homopolymerization reactions were performed using, only the octene- 1 as a monomer. This fact confirmed that the consumption of $\alpha$-olefin in the reactions occurred due to the insertion of the comonomer in the polybutadiene chains.

Figure 1 shows the influence of octene- 1 addition in different contents on the polymerization conversion.

A trend to conversion reduction was observed as the content of $\alpha$-olefin increased. According to Britto et al. ${ }^{[21]}$, this fact is justifiable because the propagation constant involving the insertion of $\alpha$-olefin in chain growth is approximately sixty times smaller than the constant which involves the insertion of diene. Moreover, the addition of $\alpha$-olefin prevents the formation of $\varpi$-structure alkyl, which stabilizes the $\sigma \mathrm{C}-\mathrm{Nd}$ (unstable) ) $^{[22]}$.

The probability of collisions between propagating species and comonomer molecules, increases with the increasing of octene-1 content. Thus, more branches can be incorporated along the polymer chain which causes a steric hindrance to the addition of new monomer molecules. This fact provoked a decrease in the conversion and is according to the literature ${ }^{[23-25]}$.

From the results obtained by FTIR, Table 1 shows that the microstructure of copolymers formed did not change with the variation of alpha-olefin content. This behavior was expected because with the presence of terminal olefins, such as octene-1, it is possible to obtain a copolymer with no changes in the structure of the material ${ }^{[16,26]}$.

The literature ${ }^{[14,16-17,23]}$ shows that the number average molecular mass (Mn) and weight average molecular mass ( $\mathrm{Mw}$ ) of copolymers, under the same conditions, should increase with the increasing of alpha-olefin content incorporated in the polybutadiene chain, as shown in Figure 2.

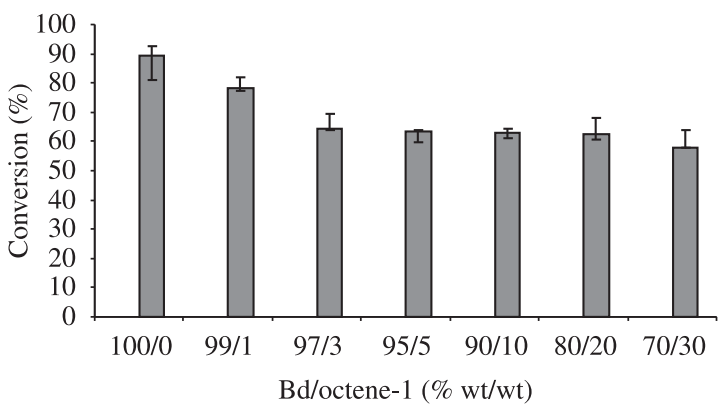

Figure 1. Influence of octene-1 addition in the reaction conversion. Catalytic system $=$ DIBAH/versatate neodymium/t-butyl chloride; $\mathrm{Al}: \mathrm{Nd}: \mathrm{Cl}=11: 1: 3$; catalyst aging $=24$ hours at $10^{\circ} \mathrm{C}$, polymerization conditions: 2 hours to $70 \pm 3{ }^{\circ} \mathrm{C} ; \mathrm{m}_{\mathrm{Bd}}=42 \mathrm{~g} ;[\mathrm{Nd}]=0.23 \mathrm{~g} \mathrm{mmol} .100^{-1} \mathrm{Bd} ; \mathrm{Bd}=$ Butadiene-1,3; solvent $=$ hexane. 
Table 1. Influence of the octene- 1 addition in copolymer microstructure.

\begin{tabular}{cccc}
\hline Butadiene-1,3/ctane-1 & \multicolumn{3}{c}{ Microstructure (\%) } \\
\cline { 2 - 4 }$(\boldsymbol{\%} \mathbf{w t} / \mathbf{w t})$ & $\mathbf{1 , 4 - c i s}$ & $\mathbf{1 , 4 - t r a n s}$ & $\mathbf{1 , 2}$-vinyl \\
\hline $100 / 0$ & 95 & 4 & 1 \\
$99 / 1$ & 94 & 5 & 1 \\
$97 / 3$ & 94 & 5 & 1 \\
$95 / 5$ & 95 & 4 & 1 \\
$90 / 10$ & 95 & 4 & 1 \\
$80 / 20$ & 95 & 4 & 1 \\
$70 / 30$ & 95 & 4 & 1 \\
\hline
\end{tabular}

Analysis conditions: solvent $=$ chloroform; solution $=2 \% \mathrm{w} / \mathrm{v}$; Catalytic system $=$ DIBAH/versatate neodymium/t-butyl chloride; Al: $\mathrm{Nd}: \mathrm{Cl}=11: 1: 3$; catalyst aging $=24$ hours at $10^{\circ} \mathrm{C}$, polymerization conditions: 2 hours to $70 \pm 3^{\circ} \mathrm{C} ; \mathrm{m}_{\mathrm{Bd}}=42 \mathrm{~g} ;[\mathrm{Nd}]=0.23 \mathrm{~g} \mathrm{mmol} .100^{-1} \mathrm{Bd}$; solvent $=$ hexane .

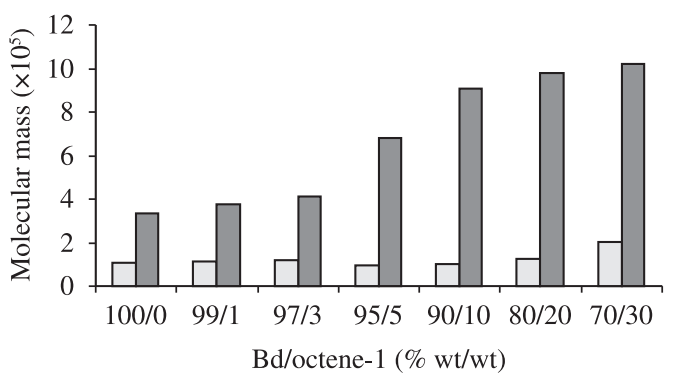

\section{$\square \mathrm{Mn} \quad \square \mathrm{Mw}$}

Figure 2. Influence of octene-1 addition on the molecular mass. Analysis conditions: Temperature $=30{ }^{\circ} \mathrm{C}$, flow $=1 \mathrm{~mL} / \mathrm{min}$; solvent $=$ THF; Solution $=0.15 \% \mathrm{w} / \mathrm{v} ; \mathrm{Bd}=$ Butadiene- 1,3 .

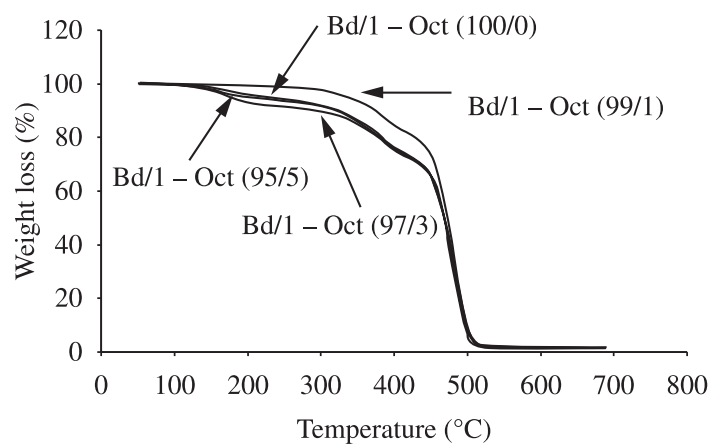

Figure 3. Influence of octene- 1 addition in thermal stability. Conditions of analysis: heating rate $=20{ }^{\circ} \mathrm{C} / \mathrm{min}$, purge gas $=\mathrm{N}_{2}$, range of the analysis $=50-700^{\circ} \mathrm{C}$, Catalytic system $=$ DIBAH $/$ versatate neodymium $/$ t-butyl chloride; $\mathrm{Al}: \mathrm{Nd}: \mathrm{Cl}=11: 1: 3$; catalyst aging $=24$ hours at $10^{\circ} \mathrm{C}$, polymerization conditions: 2 hours to $70 \pm 3{ }^{\circ} \mathrm{C} ; \mathrm{m}_{\mathrm{Bd}}=42 \mathrm{~g} ;[\mathrm{Nd}]=0.23 \mathrm{~g} \mathrm{mmol} \cdot 100^{-1} \mathrm{Bd}$; solvent $=$ hexane.

The molecular mass of a polymer depends on the number and the size of its chains ${ }^{[30-31]}$.

A tendency to molecular mass increase was observed with the increasing of alpha-olefin content (Figure 2). This pattern was already expected, since with the increasing of comonomer content in the reaction (keeping constant the mass of butadiene-1,3), higher the alpha-olefin insertion in the polymer chain, due to higher probability efficient collisions, resulting thus, in a copolymer with higher molar mass. The results showed that, by adding of alpha-olefin, under the conditions evaluated in this study, no significant changes in
Table 2. Influence of octene-1 addition in Tmax.

\begin{tabular}{cc}
\hline $\begin{array}{c}\text { Butadiene-1,3/octene-1 } \\
(\boldsymbol{\%} \text { wt/wt) }\end{array}$ & $\begin{array}{c}\text { Tmax } \\
\left({ }^{\circ} \mathbf{C}\right)\end{array}$ \\
\hline $100 / 0$ & 480 \\
$99 / 1$ & 482 \\
$97 / 3$ & 482 \\
$95 / 5$ & 483 \\
$90 / 10$ & 484 \\
$80 / 20$ & 484 \\
$70 / 30$ & 478 \\
\hline
\end{tabular}

Conditions of analysis: heating rate $=20^{\circ} \mathrm{C} / \mathrm{min}$, purge gas $=\mathrm{N}_{2}$, range of the analysis $=50-700{ }^{\circ} \mathrm{C}$, Catalytic system $=$ DIBAH $/$ versatate neodymium/t-butyl chloride; $\mathrm{Al}: \mathrm{Nd}: \mathrm{Cl}=11: 1: 3$; catalyst aging $=24$ hours at $10{ }^{\circ} \mathrm{C}$, polymerization conditions: 2 hours to $70 \pm 3^{\circ} \mathrm{C} ; \mathrm{m}_{\mathrm{Bd}}=42 \mathrm{~g} ;[\mathrm{Nd}]=0.23 \mathrm{~g} \mathrm{mmol} .100^{-1} \mathrm{Bd} ;$ solvent $=$ hexane.

the temperature at which the degradation rate is maximum (Tmax) (Table 2). These results are according to literature ${ }^{[32]}$.

It is important to emphasize that the equipment error is $\pm 4{ }^{\circ} \mathrm{C}$.

Table 2 shows that the Tmax did not change with the incorporation of octene-1 in polybutadiene chain. However, the same behavior was not found in the temperature of initial degradation (Figure 3). Observing the curves with different levels of octene-1, it is evident that the increase in alpha-olefin incorporation along the polymer chain may have promoted the formation of crystalline segments which are the result of a possible packing of branches - thereby increasing the thermal stability of the material.

\section{Conclusions}

Copolymers of butadiene -1,3 were obtained with octane- 1 . The $\alpha$-olefin addition in polybutadiene chains did not modify the structure of polymeric chains because its microstructure remained constant with the addition of octene- 1 . The copolymer molecular mass trended to increase as octene- 1 content increased. The degradation temperature (Tmax) was not affected by the addition of $\alpha$-olefin; however, the same was not observed with thermal stability.

\section{Acknowledgements}

The authors thank to Petroflex Indústria e Comércio S.A. (currently Lanxess), Conselho Nacional de Desenvolvimento Científico e Tecnológico (CNPq) and Fundação Carlos Chagas Filho de Amparo à Pesquisa do Estado do Rio de Janeiro (FAPERJ) for financial support.

\section{References}

1. Kwag, G.; Kim, P.; Han, S. \& Choi, H. - Polymer, 46, p.3782 (2005). http://dx.doi.org/10.1016/j.polymer.2005.03.040

2. Mello, I. L.; Soares, B. G.; Coutinho, F. M. B. \& Nunes, D. S. S. Polímeros, 14, p.235 (2004)

3. Kozlov, V. G.; Sigayeva, N. N.; Monakov, Y. B.; Volodina, V. P.; Savel'yeva, I. G.; Korogodova, N. A. \& Filatova, E. S. - Polym. Sci. U.R.R.S., 33, p.2296 (1991). http://dx.doi.org/10.1016/00323950(91)90080-A

4. Kwag, G. - Macromolecules, 35, p.4875 (2002). http://dx.doi. org $/ 10.1021 / \mathrm{ma} 012123 p$

5. Mello, I. L.; Coutinho, F. M. B.; Soares, B. G.; Nunes, D. S. S.; Costa, M. A. S. \& Santa Maria, L. C. - Quím. Nova, 27, p.277 (2004). http:// dx.doi.org/10.1590/S0100-40422004000200018

6. Nunes, D. S. S.; Coutinho, F. M. B. \& Mello, I. L. - Polímeros, 15, p.296 (2005). 
7. Ferreira Junior, L. C. - "Modelagem e simulação de propriedades finais de polibutadieno com alto teor de unidades cis-1,4", Tese de Doutorado, Universidade Federal do Rio de Janeiro, Brasil (2009).

8. Zhang, Z; Cui, D.; Wang, B.; Liu, B. \& Yang, Y. - "Polymerization of 1,3-conjugated dienes with rare-earth metal precursos", in Molecular catalysis of rare-earth elements, Series: Structure and bonding, Roesky (2010).

9. Ferreira Junior, L. C.; Nele, M.; Costa, M. A. S. \& Pinto, J. C. Macromol. Theory Simul., 9 (2010).

10. Pinto, J. C.; Ferreira Junior, L. C.; Nele, M.; Costa, M. A. S.; Pires, N. M. T. \& Santa-Maria, L. C. - Polym. Eng. Sci., 40 (2010).

11. Viola, G. T. \& Bacchelli, F. - Process for the preparation of polybutadiene with a low branching degree, IT n, MI 2004A000076, 5 Jan. 2005, 10 jun. (2005).

12. Neboinova, L. A.; Grechanovskii, V. A; Poddubnyi, I. Y. \& Avdeyeva, L. R. - Polym. Sci. U.S.S.R., 16, p.216 (1974). http://dx.doi. org/10.1016/0032-3950(74)90134-8

13. Makovetsky, K. L.; Yakovlev, V. A.; Golenko, T. G. \& Bondarenko, G. N. - Polym. Sci. Ser. B, 48, p.61 (2006).

14. Visseaux, M.; Barbier-Baudry, D.; Bonnet, F. \& Dormond, A. - Macromol. Chem. Phys., 202, p.2485 (2001). http://dx.doi. org/10.1002/1521-3935(20010801)202:12\%3C2485::AIDMACP2485\%3E3.0.CO;2-6

15. Barbier-Baudry, D.; Dormond, A. \& Desmurs, P. - C.R. Acad. Sci. Paris, 2, p.375 (1999).

16. Barbier-Baudry, D.; Bonnet, F.; Dormond, A.; Hafid, A.; Nyassi, A. \& Visseaux, M. - J. Alloy. Compd., 323, p.592 (2001). http://dx.doi. org/10.1016/S0925-8388(01)01184-7

17. Bonnet, F.; Barbier-Baudry, D.; Dormond, A. \& Visseaux, M. - Polym. Int., 51, p.986 (2002). http://dx.doi.org/10.1002/pi.1043

18. Schröder, G. M. \& Arndt, K. F. - "Polymer Characterization”, Hanser, Munich (1989)

19. Bialek, M. \& Czaja, K. - Polymer, 41, p.7899 (2000). http://dx.doi. org/10.1016/S0032-3861(00)00153-1

20. Koutalas, G.; Iatrou, H.; Lohse, D. J. \& Hadjichristidis, N. Macromolecules, 38, p.4996 (2005). http://dx.doi.org/10.1021/ ma047333r
21. Britto, M. L.; Galland, G. B.; Santos, J. H. Z. \& Forte, M. C - Polymer, 42, p.6355 (2001). http://dx.doi.org/10.1016/S00323861(01)00117-3

22. Mähner, C.; Kaulbach, R.; Lechter, M. D.; Nordmeier, E. H. \& Gehrke Die Angew, K. - Mackromol. Chemie., 4079, p.167 (1995).

23. Barbier-Baudry, D.; Bonnet, F.; DomenichinI, B.; Dormond, A. \& Visseaux, M. - J. Organomet. Chem., 647, p.167 (2002). http://dx.doi. org/10.1016/S0022-328X(01)01476-0

24. Lovisi, H.; Tavares, M. I. B.; Silva, N. M.; Menezes, S. M. C.; Santa Maria, L. C. \& Coutinho, F. M. B. - Polymer, 42, p.9791 (2001). http:// dx.doi.org/10.1016/S0032-3861(01)00528-6

25. Bonnet, F.; Visseaux, M.; Barbier-Baudry, D. \& Dormond, A. Macromolecules, 35, p.1143 (2005). http://dx.doi.org/10.1021/ ma011437+

26. Hwang, J.; Foster, M. D. \& Quirk, R. P. - Polymer, 45, p.873 (2004). http://dx.doi.org/10.1016/j.polymer.2003.11.047

27. Mello, I. L. - "Efeito do solvente na polimerização 1,4-cis de 1,3-butadieno com catalisadores à base de neodímio", Dissertação de Mestrado, Universidade Federal do Rio de Janeiro, Brasil (2003).

28. Mello, I. L. - "Estudo do envelhecimento de sistemas catalíticos ZieglerNatta à base de neodímio para polimerização de 1,3-butadieno", Tese de Doutorado, Universidade Federal do Rio de Janeiro, Brasil ( 2007).

29. Silva, G. M. - "Copolimerização de 1,3-butadieno e alfa-olefinas com catalisadores à base de versatato de neodímio", Dissertação de Mestrado, Universidade do Estado do Rio de Janeiro, Brasil (2010).

30. Lucas, E. F.; Soares, B. G. \& Monteiro, E. - "Caracterização de polímeros: Determinação de peso molecular e análise térmica". E-papers, Rio de Janeiro (2001).

31. Odian, G. - "Principles of polymerization", $4^{\text {th }}$ edition, John Wiley \& Sons, Inc., New Jersey (2004).

32. Jeon, K.; Palza, H.; Quijada, R. \& Alamo, R. G. - Polymer, 50, p.832 (2009). http://dx.doi.org/10.1016/j.polymer.2008.10.032

Enviado: $16 / 11 / 10$

Reenviado: $18 / 01 / 11$

Aceito: $14 / 02 / 11$

DOI: $10.1590 / \mathrm{S} 0104-14282011005000059$ 